\title{
Sickle Cell Vaso-occlusive Crisis Is Associated with Abnormalities in the Ratio of Vasoconstrictor to Vasodilator Prostanoids
}

\author{
B. N. YAMAJA SETTY, DECHUN CHEN, AND MARIE J. STUART \\ Marian Anderson Sickle Cell Anemia Care and Research Center, Division of Hematology-Oncology, St. \\ Christopher's Hospital for Children, and Temple University School of Medicine, Philadelphia, \\ Pennsylvania 19134-1095
}

\begin{tabular}{|c|c|}
\hline \multicolumn{2}{|c|}{ ABSTRACT } \\
\hline $\begin{array}{l}\text { Plasma levels of 6-keto-prostaglandin } \mathrm{F}_{1 \alpha}\left(6 \mathrm{kPGF}_{1 \alpha}\right) \text { and } \\
\text { thromboxane }(\mathrm{Tx}) \mathrm{B}_{2} \text { have been assessed in sickle cell disease } \\
\text { (SCD) with discrepant results. Inasmuch as direct measurement of } \\
\text { plasma prostanoids is fraught with the problem of interfering sub- } \\
\text { stances, we assessed plasma } 6 \mathrm{kPGF}_{1 \alpha} \text { and } \mathrm{TxB}_{2} \text { levels in patients } \\
\text { with SCD by RIA after extraction of eicosanoids and separation by } \\
\text { HPLC. We demonstrate that the } 6 \mathrm{kPGF}_{1 \alpha} \text { and } \mathrm{TxB}_{2} \text { levels in } \\
\text { children with SCD in steady state as well as in vaso-occlusive crisis } \\
\text { (VOC) are significantly lower when compared with those from } \\
\text { age-matched controls. The VOC plasma } 6 \mathrm{kPF}_{1 \alpha} \text { and } \mathrm{TxB}_{2} \text { levels } \\
\text { were, however, significantly elevated when compared with those } \\
\text { from children in steady state. Changes similar to those noted with } \\
\text { unpaired plasma samples were also observed when paired steady } \\
\text { state and VOC plasmas from the same patients were assessed. The } \\
\text { ratio of TxB } \mathrm{B}_{2} \text { to } 6 \mathrm{kPGF}_{1 \alpha} \text { was, however, significantly elevated in } \\
\text { patients with SCD in crisis when compared with eicosanoid ratios } \\
\text { obtained during steady state. In an attempt to understand whether } \\
\text { the abnormality in } 6 \mathrm{kPGF}_{1 \alpha} \text { was due to an impairment in endothe- } \\
\text { lial cell prostacyclin-regenerating ability, we compared the ability of } \\
\text { plasma from controls and children with SCD to activate arachidonic } \\
\left.\text { acid (AA) release and prostacyclin production by [ }{ }^{14} \mathrm{C}\right] \mathrm{AA}- \\
\text { prelabeled bovine aortic endothelial cells. Our results suggest that } \\
\text { the decreased } 6 \mathrm{kPGF}{ }_{1 \alpha} \text { levels in plasma from children with SCD }\end{array}$ & $\begin{array}{l}\text { was not due to an effect on substrate } \mathrm{AA} \text { release but rather a } \\
\text { modulatory effect of sickle plasma components on endothelial cell } \\
\text { cyclooxygenase activity. Although a decreased production of pros- } \\
\text { tacyclin has previously been suggested to play a role in the initiation } \\
\text { and/or propagation of vaso-occlusion in } \mathrm{SCD} \text {, our study demon- } \\
\text { strates a relative increase during VOC of } 6 \mathrm{kPGF}_{1 \alpha} \text { levels over those } \\
\text { observed in steady state. However, the rise in } 6 \mathrm{kPGF}_{1 \alpha} \text { is accom- } \\
\text { panied by an increase in levels of } \mathrm{TxB}_{2} \text { such that the ratio of } \mathrm{TxB}_{2} \\
\text { to } 6 \mathrm{kPGF}_{1 \alpha} \text { is significantly increased during VOC. The imbalance } \\
\text { in the production of vasoactive eicosanoids, TxA } \mathrm{A}_{2} \text { and prostacyclin, } \\
\text { could potentially play a role in the potentiation of VOC in patients } \\
\text { with SCD. (Pediatr Res 38: } 95-102,1995 \text { ) } \\
\text { SCD, sickle cell disease } \\
\text { VOC, vaso-occlusive crisis } \\
\text { HBSS, Hanks' balanced salt solution } \\
\text { AA, arachidonic acid } \\
\text { PG, prostaglandin } \\
\text { 6kPGF } \\
\text { Tx, thromboxane-prostaglandin } \mathrm{F}_{1 \alpha} \\
\text { HETE, hydroxyeicosatetraenoic acid } \\
\text { HEPES, } N \text {-2-hydroxyethylpiperazine- } \mathrm{N}^{\prime}-2 \text {-ethanesulfonic acid }\end{array}$ \\
\hline
\end{tabular}

Intermittent episodes of vaso-occlusion are one of the major clinical problems in SCD. Vaso-occlusion is a complex process involving interactions of multiple components including sickle red blood cells, other circulating cellular elements of blood, plasmatic factors, and vascular endothelial cells $(1,2)$. Endothelial cells generate several vasoactive agents including prostacyclin, a potent vasodilator and anti-thrombotic eicosanoid, whereas activated platelets produce $\mathrm{TxA}_{2}$, a potent vasocon-

Correspondence and reprint requests: B.N.Y. Setty, Ph.D., Division of HematologyOncology, St. Christopher's Hospital for Children, Erie Ave. at Front St., Philadelphia, PA 19134-1095.

Supported by the National Institutes of Health, U.S. Public Health Service Grants HL45969 and HL51497, and a grant from the American Heart Association, Southeastern Pennsylvania Affiliate. strictor and prothrombotic eicosanoid. Several previous studies have shown that the balance between the biosynthesis of these two vasoactive eicosanoids with contrasting biologic properties plays an important role in the maintenance of hemostasis $(3,4)$. Abnormalities in the production of these vasoactive agents have previously been observed in various pathologic conditions associated with vascular complications $(5,6)$. Circulatory levels of both $6 \mathrm{kPGF}_{1 \alpha}$ and $\mathrm{TxB}_{2}$, the stable nonenzymatic hydrolysis products of prostacyclin and $\mathrm{TxA}_{2}$, respectively, in SCD have also been assessed by several investigators with discrepant results (7-12). These discrepancies are not surprising because the direct measurement of these eicosanoids in plasma or serum by RIA is fraught with the problem of interfering substances. In the present study, we have measured 
plasma levels of both $6 \mathrm{kPGF}_{1 \alpha}$ and $\mathrm{TxB}_{2}$ in patients with $\mathrm{SCD}$ by RIA after extraction of eicosanoids from plasma, and separation by reverse phase-HPLC. Our results demonstrate that the levels of both $6 \mathrm{kPGF}_{1 \alpha}$ and $\mathrm{TxB}_{2}$ in children with $\mathrm{SCD}$ in steady state are significantly lower when compared with those from age-matched controls. During VOC, although the levels rise when compared with steady state, they were still below normal control values. Additional in vitro studies suggest that the decreased $6 \mathrm{kPGF}_{1 \alpha}$ level in plasma from patients with SCD in steady state was due to a modulatory effect of sickle plasma components on endothelial cell cyclooxygenase activity.

\section{METHODS}

Materials. Reference eicosanoid standards for chromatographic analysis were obtained from Biomol Research Laboratories (Plymouth Meeting, PA). AA, adenosine, theophylline, indomethacin, and nordihydroguaiaretic acid were purchased from Sigma Chemical Co. (St. Louis, MO). $\left[{ }^{3} \mathrm{H}\right] \mathrm{PGB}_{1}(56$ $\mathrm{Ci} / \mathrm{mmol}),\left[{ }^{3} \mathrm{H}\right] 6 \mathrm{kPGF}_{1 \alpha}(199 \mathrm{Ci} / \mathrm{mmol}),\left[{ }^{3} \mathrm{H}\right] \mathrm{TxB}_{2}(209 \mathrm{Ci} /$ $\mathrm{mmol})$, and $\left[1-{ }^{14} \mathrm{C}\right] \mathrm{AA}(50-60 \mathrm{mCi} / \mathrm{mmol})$ were obtained from Amersham Corp. (Arlington Heights, IL) or Dupont NEN (Boston, MA). Tissue culture supplies were purchased from Life Technologies, Inc. (Grand Island, NY).

Culture of endothelial cells. Fetal bovine aortic endothelial cells were isolated, identified, and cultured in minimal essential medium supplemented with $10 \%$ FCS as described by Glaser $e t$ al. (13). Cells from passages 8-16 were used in the experiments to be described, each passage representing two-cell doubling.

Blood collection and preparation of plasma. After informed consent, venous blood (5-10 mL) was obtained from healthy volunteers ( $n=15$, ages $2-21 \mathrm{y}$, mean age $9.6 \mathrm{y})$ and patients with $\operatorname{SCD}(n=42$, ages $2-22 \mathrm{y}$, mean age $11.9 \mathrm{y})$. The latter patient group included 35 patients homozygous for hemoglobin SS and seven patients with SC disease. The mean ages of both SS (ages 2-22 y, mean age 12.4 y) and SC (ages 2-21 y, mean age 9.6 y) patient groups were similar. Crisis blood samples ( $n$ $=19$, ages $4-19 \mathrm{y}$, mean age $12.9 \mathrm{y}$ ) were obtained from patients in VOC within the first $24-48 \mathrm{~h}$ of the crisis event. Eight SS patients were studied under both steady state and crisis conditions. VOC was identified by the acute onset of bone pain in an afebrile patient who had no concomitant respiratory findings by clinical or radiologic examination and who had no clinical or laboratory evidence of infection. All patients in VOC were on analgesics (morphine, demerol, or codeine) and none was on nonsteroidal anti-inflammatory drugs. For evaluation of the effect of plasma on endothelial cell prostacyclin production, blood was collected in tubes containing either sodium heparin or acid-citrate-dextrose as an anticoagulant. For measurement of plasma $6 \mathrm{kPGF}_{1 \alpha}$ and $\mathrm{TxB}_{2}$ levels, blood was collected in acid-citrate-dextrose tubes containing nordihydroguaiaretic acid, indomethacin, adenosine, and theophylline added to a final concentrations of $25 \mu \mathrm{M}, 30$ $\mu \mathrm{M}, 100 \mathrm{mM}$, and $1 \mathrm{mM}$, respectively. The latter pharmacologic agents were added to suppress platelet activation and eicosanoid production. All blood samples were centrifuged at
$3000 \times g$ for $20 \mathrm{~min}$ at room temperature to remove platelets, white blood cells, and red blood cells. All plasma samples were stored frozen at $-80^{\circ} \mathrm{C}$ until assayed.

Measurement of plasma $6 \mathbf{k P G F}_{1 \alpha}$ and $T \mathbf{x} \mathrm{B}_{2}$ levels. Plasma (3-5 mL) was diluted with an equal volume of ice-cold methanol, 50,000 cpm of HPLC re-purified $\left[{ }^{3} \mathrm{H}\right] \mathrm{PGB}_{1}$ was added to each sample to monitor for the recovery of prostanoids, and the mixture was then incubated overnight at $-20^{\circ} \mathrm{C}$ to precipitate plasma proteins. The methanol content in the protein-free extract was adjusted to $10 \%$, and eicosanoids in the methanolic extract were isolated using C-18 Maxi-Clean 600-mg cartridges (Alltech Associates, Deerfield, IL) as previously described (14). To the isolated eicosanoid fraction, $75 \mathrm{ng}$ of unlabeled $\mathrm{PGB}_{1}$ were added, and the samples were concentrated to dryness using a SpeedVac Concentrator. Lipids were reconstituted in the HPLC mobile phase and analyzed on a 4.6 $\times 125 \mathrm{~mm}$ Whatman's PartiSphere C-18 column (Whatman Chemical Separation, Clifton, NJ), and a Beckman liquid chromatograph (Beckman Instrument, Palo Alto, CA) using a stepwise gradient of acetonitrile and $0.1 \%$ acetic acid in water at a flow rate of $1 \mathrm{~mL} / \mathrm{min}$. Solvent $\mathrm{A}$ was acetonitrile-wateracetic acid (30:70:0.1\%, by volume), and solvent B was acetonitrile (100\%). The solvent program was as follows: $100 \% \mathrm{~A}$ for 13 min, a quick gradient from $0 \%$ to $24 \%$ B over 2 min, and the gradient was held at $24 \% \mathrm{~B}$ for an additional $10 \mathrm{~min}$. The column was washed with $100 \%$ solvent $\mathrm{B}$ for 15 min between injections. The elution of reference prostanoids was monitored continuously at 210 and $280 \mathrm{~nm}$ with a Beckman 165 variable wavelength detector. Under these HPLC conditions, reference $6 \mathrm{kPGF}_{1 \alpha}, \mathrm{TXB}_{2}, \mathrm{PGF}_{2 \alpha}, \mathrm{PGE}_{2}, \mathrm{PGD}_{2}$, and $\mathrm{PGB}_{1}$ eluted at $4.96 \pm 0.08$ (mean $\pm \mathrm{SD}, n=8$ ), $9.01 \pm 0.15,12.84 \pm 0.21$, $15.37 \pm 0.25,17.23 \pm 0.11$, and $20.76 \pm 0.08 \mathrm{~min}$, respectively. Fractions $(30 \mathrm{~s})$ were collected for up to $25 \mathrm{~min}$, and the material eluting in the regions of $6 \mathrm{kPGF}_{1 \alpha}$, and $\mathrm{TxB}_{2}$ were pooled separately. After evaporation of HPLC mobile phase, both $6 \mathrm{kPGF}_{1 \alpha}$ and $\mathrm{TxB}_{2}$ fractions were reconstituted in $500 \mu \mathrm{L}$ of RIA buffer, and aliquots were assayed for $6 \mathrm{kPGF}_{1 \alpha}$ and $\mathrm{TxB}_{2}$ using commercially available RIA kits (Advanced Magnetics Inc., Boston, MA), respectively. The lower limits of these assays sensitivity were 7.4 and $22.2 \mathrm{fmol}$ per $100 \mu \mathrm{L}$ for $6 \mathrm{kPGF}_{1 \alpha}$ and $\mathrm{TxB}_{2}$, respectively. The elution of $\left[{ }^{3} \mathrm{H}\right] \mathrm{PGB}_{1}$ was monitored with a Ramona-5-LS flow-through radioisotope detector (Raytest USA Inc., Pittsburgh, PA) equipped with a solid scintillator. The radioactivity eluting in the $\mathrm{PGB}_{1}$ area was pooled, and activity determined in a LKB Mini-Beta liquid scintillation counter (Pharmacia Biotech Inc., Gaithersburg, MD) using Liquiscint (National Diagnostics, Atlanta, GA). The recovery of $\left[{ }^{3} \mathrm{H}\right] \mathrm{PGB}_{1}$ through $\mathrm{HPLC}$ was $76 \pm 1 \%(n=$ 18). In separate experiments, the recoveries of both $\left[{ }^{3} \mathrm{H}\right] 6 \mathrm{kPGF}_{1 \alpha}$ and $\left[{ }^{3} \mathrm{H}\right] \mathrm{TxB}_{2}$ through HPLC were found to be similar to that of $\left[{ }^{3} \mathrm{H}\right] \mathrm{PGB}_{1}$ when analyzed under identical experimental conditions. $6 \mathrm{kPGF}_{1 \alpha}$ and $\mathrm{TxB}_{2}$ levels corrected for $\left[{ }^{3} \mathrm{H}\right] \mathrm{PGB}_{1}$ recovery were expressed as picomoles $/ \mathrm{mL}$ plasma and ratios of $\mathrm{TxB}_{2}$ to $6 \mathrm{kPGF}_{1 \alpha}$ were determined for each individual evaluated.

Effect of plasma on endothelial cell prostacyclin regenerating ability. Endothelial cells from stock cultures were seeded into wells of six-well plates, grown to confluence, and then 
prelabeled with $\left[{ }^{14} \mathrm{C}\right] \mathrm{AA}$ as previously described (15). In brief, confluent cell monolayers were incubated for $20 \mathrm{~h}$ with $2.5 \mu \mathrm{M}$ $\left[{ }^{14} \mathrm{C}\right] \mathrm{AA}$ provided in $2 \mathrm{~mL}$ of minimal essential medium containing $10 \%$ FCS. Under this labeling condition, endothelial cells incorporated approximately $80 \%$ of the added $\left[{ }^{14} \mathrm{C}\right] \mathrm{AA}$ into the membrane phospholipids. The $\left[{ }^{14} \mathrm{C}\right] \mathrm{AA}-$ labeled washed endothelial cell monolayers were incubated for the indicated times in the presence of $1.5 \mathrm{~mL}$ of 1 to 1 diluted plasma in HBSS containing $1.3 \mathrm{mM} \mathrm{CaCl}$ and $0.5 \mathrm{mM} \mathrm{MgCl} 2$ buffered with $5 \mathrm{mM}$ HEPES (HBSS-HEPES buffer) or HBSSHEPES buffer alone. After incubation, metabolites from the pooled incubation medium and endothelial cells were extracted (16), evaporated, and reconstituted in $100 \mu \mathrm{L}$ of chloroform. Aliquots were analyzed by thin layer chromatography on silica gel G plates (Analtech, Inc., Newark, DE) using the upper phase of ethyl acetate-isooctane-acetic acid-water (90:50:20:100, by volume) as a solvent system (17). Reference prostaglandins, HETE, and AA (5 $\mu \mathrm{g} / \mathrm{spot})$ were run on the same plates and visualized using a cupric acetate spray reagent (Applied Science Labs., Deerfield, IL). After radioautography, the eicosanoid bands were identified by comparing their retention factor values with those of authentic standards. Radioactive bands were scraped into scintillation vials and extracted with $500 \mu \mathrm{L}$ of methanol, and radioactivity was determined using $4.5 \mathrm{~mL}$ of Liquiscint. The sum of radioactivity recovered in various prostanoids, HETE, and the free fatty acid fraction was used as a measure of endothelial cell AA release. Cyclooxygenase activity was assessed by measuring the radioactivity recovered in the various prostanoids including $6 \mathrm{kPGF}_{1 \alpha}$ (the nonenzymatic hydrolysis product of prostacyclin), $\mathrm{PGE}_{2}$, and $\mathrm{PGF}_{2 \alpha}$. Conversion of mobilized AA to prostacyclin or total prostanoids was expressed as the percent ratio of radioactivity recovered in products to total AA released.

Statistical analysis. Statistical evaluation was performed either by the unpaired or paired $t$ test.

\section{RESULTS}

\section{Plasma Prostanoid Levels in Children with Sickle Cell Disease}

Comparison of plasma $6 \mathrm{KPGF}_{1 \alpha}$ levels measured with direct assay of plasma versus assay after extraction and HPLC separation. Plasma $6 \mathrm{kPGF}_{1 \alpha}$ levels were measured in blood samples obtained from 18 different donors either directly (using 25-100 $\mu \mathrm{L}$ plasma in the RIA) or following extraction of plasma eicosanoids and HPLC separation of $6 \mathrm{kPGF}_{1 \alpha}$. When $100 \mu \mathrm{L}$ plasma (the maximal volume that could be included in the RIA) was assayed directly, 10 out of 18 of these samples had measurable $6 \mathrm{kPGF}_{1 \alpha}$ levels which ranged from 0.09 to $0.68 \mathrm{pmol} / \mathrm{mL}$, whereas in the remaining eight samples the levels were either undetectable or below the lower limit of the assay's sensitivity. For calculation of mean $6 \mathrm{kPGF}_{1 \alpha}$ levels, the plasma levels in these latter eight samples were assumed to be zero. The mean $6 \mathrm{kPGF}_{1 \alpha}$ level measured in these plasma samples was $0.18 \pm$ 0.06 (mean $\pm \mathrm{SE}, n=18$ ) $\mathrm{pmol} / \mathrm{mL}$. Although all of these samples were assayed in triplicate volumes $(25,50$, and $100 \mu \mathrm{L})$, only seven out of 18 of these samples had measurable eicosanoid levels with $50 \mu \mathrm{L}$ plasma, whereas no $6 \mathrm{kPGF}_{1 \alpha}$ was detected when $25 \mu \mathrm{L}$ plasma were used in the assay. Although the variability among the duplicates generated using multiple aliquots of the same volume was within $5 \%$, there was no linearity between the volume of plasma assayed versus $6 \mathrm{kPGF}_{1 \alpha}$ levels measured. The $6 \mathrm{kPGF}_{1 \alpha}$ levels measured per mL plasma using 50 and 100 $\mu \mathrm{L}$ of plasma in the RIA were significantly different $(0.21 \pm 0.04$, and $0.47 \pm 0.11 \mathrm{pmol} / \mathrm{mL}$, respectively, $n=7, p<0.05$ ). In contrast, when $6 \mathrm{kPGF}_{1 \alpha}$ levels were measured in the same 18 plasma samples after extraction and HPLC separation, the values ranged from 0.15 to $9.93 \mathrm{pmol} / \mathrm{mL}$ with a mean ( $\pm \mathrm{SE}$ ) value of $1.64( \pm 0.57) \mathrm{pmol} / \mathrm{mL}$ plasma. Further, there was a linear response between the volume of extract assayed versus $6 \mathrm{kPGF}_{1 \alpha}$ levels measured. Finally, there was a 10 -fold difference between the $6 \mathrm{kPGF}_{1 \alpha}$ levels measured by direct assay of plasma (with 100 $\mu \mathrm{L}$ ) and the levels measured after extraction and HPLC separation of eicosanoids. This difference was statistically significant at a $p$ $<0.025$.

Plasma $6 \mathbf{k P G} F_{1 \alpha}$ levels in children with SCD. As seen in Fig. 1, panel $A$, plasma $6 \mathrm{kPGF}_{1 \alpha}$ levels in control healthy children ranged from 1.08 to $9.93 \mathrm{pmol} / \mathrm{mL}$ ( $3.60 \pm 0.88 \mathrm{pmol} / \mathrm{mL}$, mean $\pm \mathrm{SE}, n=9)$. In contrast, the $6 \mathrm{kPGF}_{1 \alpha}$ levels from children with SCD in steady state were significantly lower $(0.46 \pm 0.08 \mathrm{pmol} /$ $\mathrm{mL}, n=20, p<0.001)$. No differences in steady state $6 \mathrm{kPGF}_{1 \alpha}$ levels were noted when the SS $(0.46 \pm 0.08 \mathrm{pmol} / \mathrm{mL}, n=13)$ and $\mathrm{SC}(0.50 \pm 0.15 \mathrm{pmol} / \mathrm{mL}, n=7)$ groups were compared. The $6 \mathrm{kPGF}_{1 \alpha}$ levels in plasma from patients with SCD in VOC were $1.41 \pm 0.31 \mathrm{pmol} / \mathrm{mL}(n=13)$. Although the levels of $6 \mathrm{kPGF}_{1 \alpha}$ in this patient group were also significantly lower when compared with those from controls $(p<0.025)$, they were significantly higher when compared with sickle cell patients in steady state $(p<0.005)$. As depicted in Fig. 2, panel A, results similar to those found with unpaired plasma samples were also observed when paired steady state and VOC plasma from eight patients with SCD were compared. Although the mean $6 \mathrm{kPGF}_{1 \alpha}$ level in steady state plasma was $0.31 \pm 0.11 \mathrm{pmol} / \mathrm{mL}$, during VOC the $6 \mathrm{kPGF}_{1 \alpha}$ level in these patients was increased to $1.20 \pm 0.36$ pmol $(n=8, p<0.05)$.
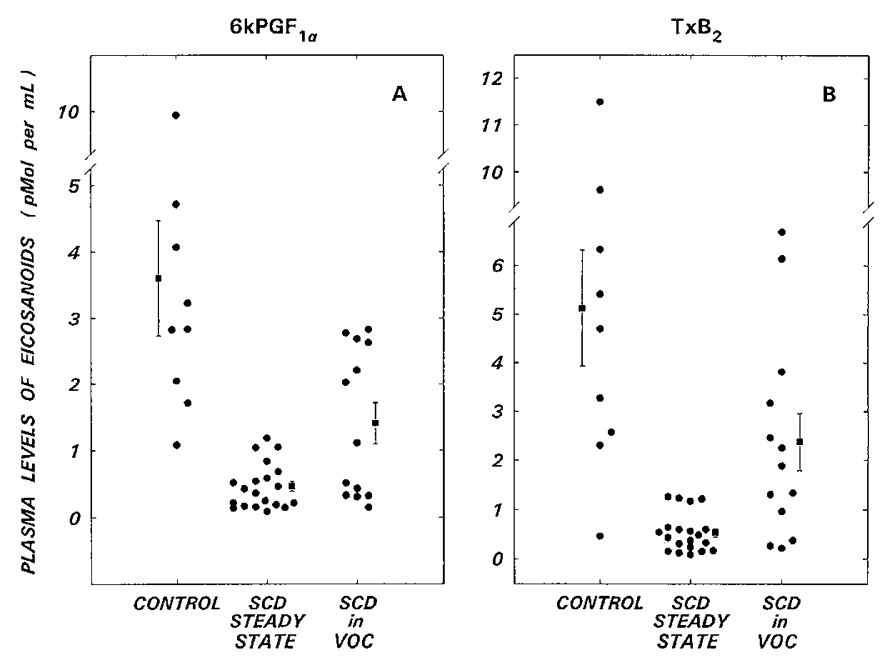

Figure 1. Plasma levels of $6 \mathrm{kPGF}_{1 \alpha}$ (panel $A$ ), and $\mathrm{TxB}_{2}$ (panel $B$ ) from control donors $(n=9)$ are compared with those from patients with SCD during steady state $(n=20)$ and in VOC $(n=13)$ 

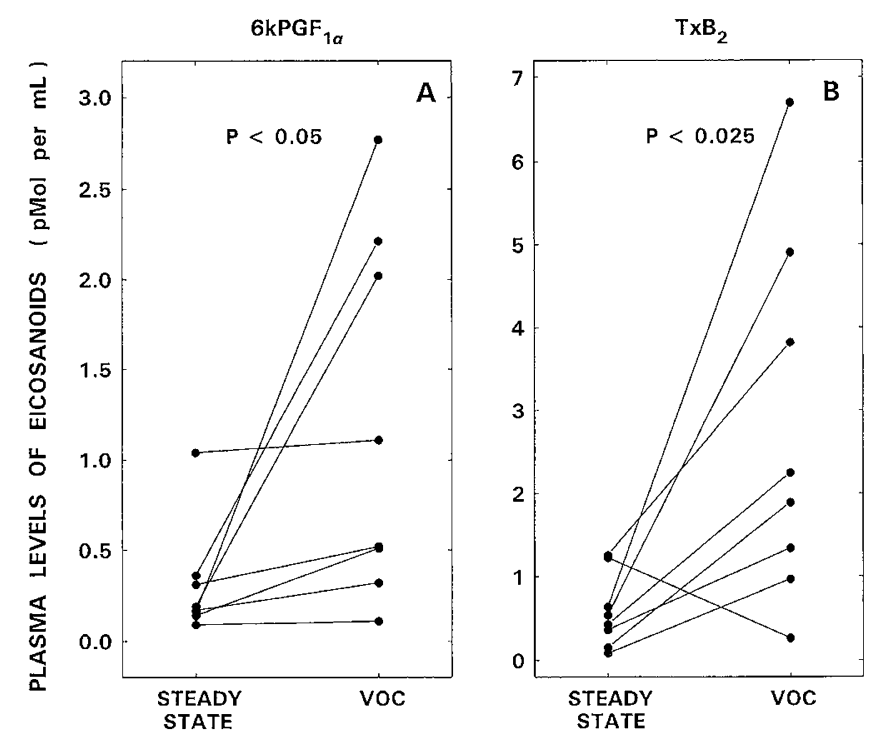

Figure 2. Plasma levels of $6 \mathrm{kPGF}_{1 \alpha}$ (panel $A$ ), and $\mathrm{TxB}_{2}$ (panel $B$ ) from eight patients with $\mathrm{SCD}$ in steady state are compared to plasmas obtained from the same patients during VOC.

Plasma $T \mathrm{~TB}_{2}$ levels in children with $\mathrm{SCD}$. Changes similar to those seen with plasma $6 \mathrm{kPGF}_{1 \alpha}$ were also observed when plasma $\mathrm{TxB}_{2}$ levels were compared among these patient groups, i.e. $\mathrm{TxB}_{2}$ levels were significantly lower in children with SCD in steady state $(0.54 \pm 0.09 \mathrm{pmol} / \mathrm{mL}$ plasma, mean $\pm \mathrm{SE}, n=20, p$ $<0.001)$ when compared with those from control healthy children $(5.13 \pm 1.19 \mathrm{pmol} / \mathrm{mL}, n=9)$ (Fig. 1 , panel $B)$. There were no differences in steady state $\mathrm{TxB}_{2}$ levels when patients with SS $(0.51 \pm 0.12 \mathrm{pmol} / \mathrm{mL}, n=13)$ and SC $(0.57 \pm 0.12 \mathrm{pmol} / \mathrm{mL}$, $n=7$ ) disease were compared. Although the plasma $\mathrm{TxB}_{2}$ levels in patients with SCD in VOC $(2.38 \pm 0.58 \mathrm{pmol} / \mathrm{mL}, n=13)$ were also significantly decreased when compared with the values noted in controls $(p<0.025)$, the levels were significantly elevated when compared with those obtained during steady state $(p$ $<0.001$ ) (Fig. 1, panel B). Similar differences in $\mathrm{TxB}_{2}$ levels in patients with SCD in steady state versus VOC were also observed when VOC plasma $\mathrm{TxB}_{2}$ levels were compared with the patient's own steady state levels $(2.77 \pm 0.78 \mathrm{pmol} / \mathrm{mL}$ in VOC versus $0.59 \pm 0.16 \mathrm{pmol} / \mathrm{mL}$ in steady state, $n=8, p<0.025$, Fig. 2 , panel $B$ ). The ratios of $\mathrm{TxB}_{2}$ to $6 \mathrm{kPGF}_{1 \alpha}$ calculated for all patient groups included values of $1.99 \pm 0.29(n=9), 1.41 \pm 0.19(n=$ $20)$, and $3.86 \pm 1.23(n=13)$ for controls, and patients with SCD in steady state and crisis, respectively. Thus, a significant increase in the ratio of $\mathrm{TxB}_{2}$ to $6 \mathrm{kPGF}_{1 \alpha}$ was observed during VOC $(p$ $<0.025$ ) when compared with steady state. Such an increase was also noted when paired data comparing steady state and VOC ratios in the same patient were contrasted $(1.61 \pm 0.29$ vs $3.62 \pm$ 0.60 , respectively, $n=8, p<0.025$ ).

\section{Effect of Sickle Cell Plasma on Endothelial Cell Prostacyclin-Regenerating Ability}

Time course of prostacyclin production and $A A$ release. In our previous studies using bradykinin as a stimulus we have shown that the prostacyclin production by bovine aortic endothelial cells reached a maximum by $45 \mathrm{~min}$ (15). In preliminary experiments, endothelial cells incubated with buffer alone released 8354 to $9298 \mathrm{cpm}\left[{ }^{14} \mathrm{C}\right] \mathrm{AA}$ between 10 and $75 \mathrm{~min}$. Endothelial cell monolayers incubated with both control plasma and plasma from patients with $\mathrm{SCD}$ released $\left[{ }^{14} \mathrm{C}\right] \mathrm{AA}$ in a time-dependent manner between 10 and 75 min with maximal stimulation observed by $45 \mathrm{~min}$. The stimulatory responses noted at 60 and $75 \mathrm{~min}$ were not significantly different from that observed at $45 \mathrm{~min}$. We have, therefore, selected a 45-min incubation time to compare the effects of plasmas from controls and patients with SCD on prostacyclin production and AA release.

Assay variabilities. In preliminary studies, we evaluated intra- and interassay variability on AA release and prostanoid production by endothelial cells using cultures from different passages. We have found that the intraassay variability was less than 5\% among paired cultures from the same passage. However, there was considerable variation in AA release and prostanoid production among cultures from different passages with 20 to $300 \%$ interassay variability. Because of the latter, plasma prostacyclin-regenerating ability was expressed as percent of buffer control to facilitate comparisons among cultures from different passages. When the effect of steady state and VOC plasmas from the same patient with SCD was compared, paired endothelial cell monolayers from the same passage were employed.

Effect of plasma on prostacyclin generation. Using endothelial cell cultures, in preliminary studies we compared the effects of paired plasmas (prepared in tubes containing either citrate or sodium heparin as the anticoagulant) on endothelial cell prostacyclin production. We found no differences in prostacyclin production when the endothelial cells were incubated with plasma prepared using either anticoagulant (4060 \pm 393 cpm $6 \mathrm{kPGF}_{1 \alpha}$ per culture dish with citrated plasma versus $3995 \pm 425 \mathrm{cpm}$ with heparinized plasma, mean $\pm \mathrm{SE}, n=5$, $p=$ NS). Because citrated plasma in our preliminary experiments clotted when diluted with the calcium-supplemented buffer used in our prostacyclin-generating experiments, heparinized plasmas were used in our subsequent studies. Endothelial cells incubated with buffer alone produced $2521 \pm 168$ cpm ${ }^{14} \mathrm{C}-6 \mathrm{kPGF}_{1 \alpha}$ per culture dish $(n=17)$. As shown in Figure 3, plasma from control donors stimulated endothelial cell prostacyclin production by $77 \%$ over baseline $(177 \pm 17 \%$ of buffer control, $n=15$ ). Plasma from patients with SCD in steady state had $29 \%$ stimulation over baseline $(129 \pm 8 \%$ of buffer control, $n=15$ ), whereas VOC plasma stimulated the production of prostacyclin by $106 \%$ over baseline $(206 \pm 16 \%$ of buffer control, $n=12$ ). Although the changes in prostacyclin-generating ability observed between control plasma and plasma from patients with SCD in VOC were not significantly different, the steady state plasma prostacyclin-regenerating activity was markedly decreased when compared with both control $(p<0.001)$ and VOC plasmas $(p<0.025)$. There were no differences when prostacyclin-regenerating ability of SS and SC plasma were compared. Differences similar to those observed with unpaired plasma samples were also found when paired steady state and VOC plasmas from the same patient 


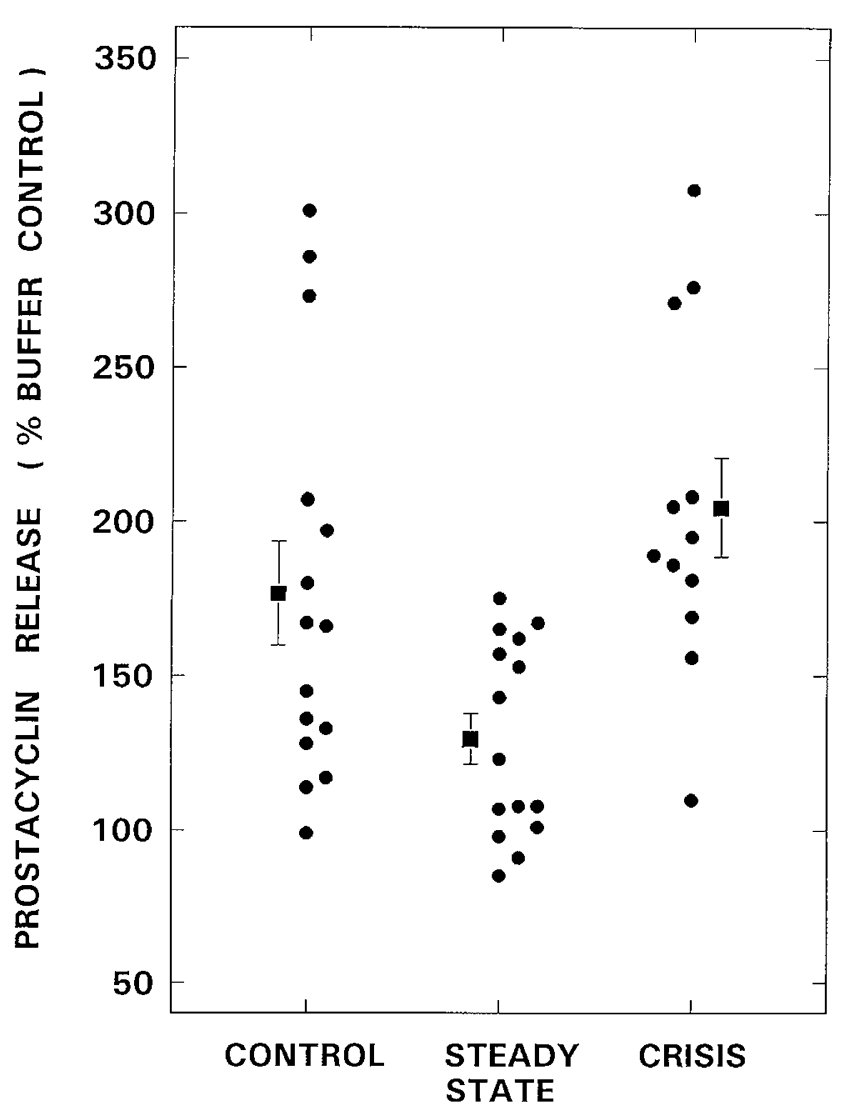

Figure 3. Comparative effects of plasmas from control donors $(n=15)$ and those from patients with SCD during steady state $(n=15)$ and in VOC $(n=$ 12) on $\left[{ }^{14} \mathrm{C}\right]$ prostacyclin production by $\left[{ }^{14} \mathrm{C}\right] \mathrm{AA}$-labeled bovine aortic endothelial cells.

with SCD were compared (Fig. 4, panel A). Although steady state plasma produced $3907 \pm 523 \mathrm{cpm} 6 \mathrm{kPGF}_{1 \alpha}$ per culture dish $(n=7)$, VOC plasma released $5276 \pm 353 \mathrm{cpm}$. These changes were significant at a $p<0.025$.
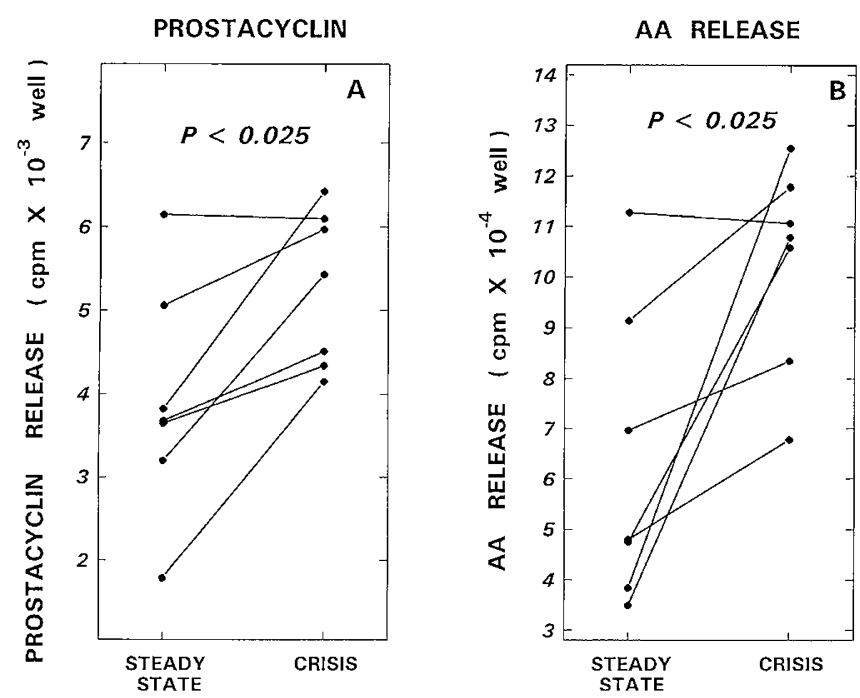

Figure 4. Comparative effects of plasmas obtained from the same patients with $\mathrm{SCD}(n=7)$ during steady state and in VOC on prostacyclin production (panel $A$ ) and AA release (panel $B$ ) by $\left[{ }^{14} \mathrm{C}\right] \mathrm{AA}-$ labeled bovine aortic endothelial cells.

\section{Localization of Defects in SCD Plasma on Endothelial Cell Prostacyclin-Regenerating Ability}

Effect of plasma on AA release. Endothelial cells incubated with buffer alone released $13058 \pm 1063 \mathrm{cpm}$ (mean $\pm \mathrm{SE}, n$ $=17)\left[{ }^{14} \mathrm{C}\right] \mathrm{AA}$ per culture dish. As depicted in Fig. 5, both control and steady state plasma stimulated AA release to the same extent. While control plasma stimulated AA release by $432 \%$ over baseline (532 $\pm 64 \%$ of buffer control, $n=15$ ), SCD steady state plasma stimulated AA mobilization by $331 \%$ over baseline ( $431 \pm 56 \%$ of buffer control, $n=15$ ). An even greater stimulatory response on AA release was seen with plasma from SCD patients in VOC with $885 \%$ stimulation over baseline (985 $\pm 156 \%$ of buffer control, $n=12$ ). The AA mobilizing effect of VOC plasma was statistically different from both control plasma- and steady state plasma-induced changes at $p<0.01$, and $p<0.005$, respectively. As seen in Fig. 4 , panel $B$, results similar to those obtained with unpaired treatments were also noted when paired plasma samples obtained from the same individual under both steady state and VOC conditions were concomitantly evaluated. Although steady state plasma released $63,237 \pm 11,117 \mathrm{cpm}$ AA per well $(n=7)$, VOC plasma mobilized $102,706 \pm 7623 \mathrm{cpm}$. This response was statistically significant at a $p<0.025$.

Effect of plasma on conversion of released AA to prostacyclin. Endothelial cells treated with control plasma converted $8.89 \pm 0.11 \%$ (mean $\pm \mathrm{SE}, n=15$ ) of the released AA into prostacyclin. Conversion of the mobilized AA to prostacyclin

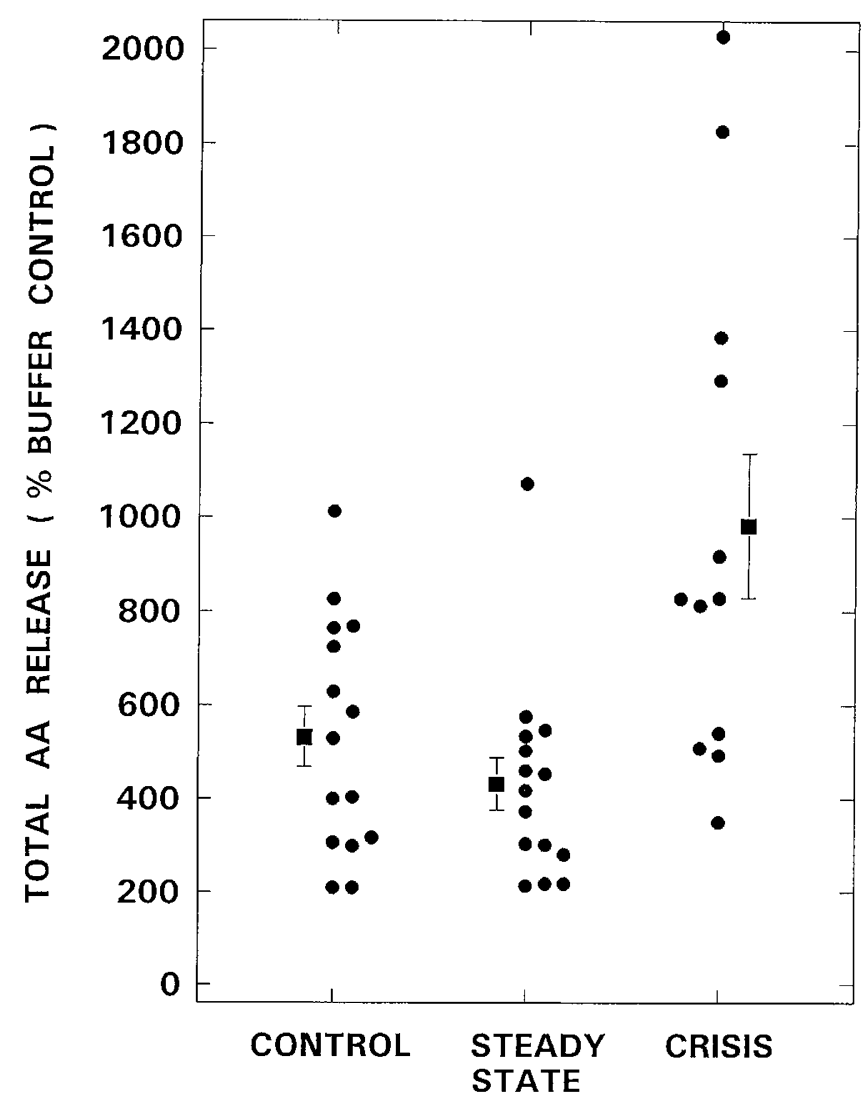

Figure 5. Comparative effects of plasmas from control donors $(n=15)$ and those from patients with SCD during steady state $(n=15)$ and in VOC $(n=$ 12) on $\left[{ }^{14} \mathrm{C}\right] \mathrm{AA}$ release by $\left[{ }^{14} \mathrm{C}\right] \mathrm{AA}-$ labeled bovine aortic endothelial cells. 
was significantly reduced in cells incubated with plasma from patients with SCD in steady state $(6.21 \pm 0.66 \%, n=15, p$ $<0.01)$. Such a reduction in AA metabolism was also observed in endothelial cells incubated with plasma from SCD patients in VOC $(6.86 \pm 0.72 \%, n=12, p<0.05)$. Thus, although steady state and VOC plasma mobilized differing amounts of AA from endothelial cells (Fig. 5), the conversion of mobilized AA to prostacyclin was similar under both steady state and VOC conditions. Similar results were also obtained when AA conversion to prostacyclin was analyzed in the presence of the paired steady state and VOC plasma samples from the same individual patient with SCD $(6.48 \pm 0.68 \%$ versus $6.43 \pm$ $0.43 \%, n=7)$. When the effect of plasma on endothelial cell cyclooxygenase activity was assessed, although control plasma and VOC plasma enhanced prostanoid formation by $40 \%$ (140 $\pm 12 \%$ of buffer control, $n=15)$ and $57 \%$ over baseline $(157$ $\pm 12 \%$ of buffer control, $n=12$ ), the prostanoid-regenerating ability of steady state plasma was significantly decreased (108 $\pm 6 \%$ of buffer control, $n=15$ ). These latter changes were statistically significant at $p<0.025$ and $p<0.05$, respectively.

\section{DISCUSSION}

We measured plasma levels of $6 \mathrm{kPGF}_{1 \alpha}$ and $\mathrm{TxB}_{2}$ - the stable nonenzymatic hydrolysis products of prostacyclin and $\mathrm{TxA}_{2}$, respectively, in patients with $\mathrm{SCD}$ after extraction and HPLC separation of these eicosanoids. Our results demonstrate that the levels of $6 \mathrm{kPGF}_{1 \alpha}$ in patients with SCD in steady state are significantly lower when compared with those from agematched controls. During VOC, although the levels tend to rise above steady state, they were still below the normal range. Similar changes in serum $6 \mathrm{kPGF}_{1 \alpha}$ levels between control donors and patients with SCD in steady state have previously been reported by Longenecker and co-workers (Table 1). These investigators also found that the crisis $6 \mathrm{kPGF}_{1 \alpha}$ levels were marginally higher than the steady state levels (Table 1). In contrast to our present results and those of Longenecker, other investigators have found increased $6 \mathrm{kPGF}_{1 \alpha}$ levels in plasma from patients with SCD (Table 1). In concomitant studies, we also measured plasma $\mathrm{TxB}_{2}$ levels in these patients and demonstrated changes in this eicosanoid similar to those observed with $6 \mathrm{kPGF}_{1 \alpha}$, i.e. the steady state $\mathrm{TxB}_{2}$ levels were significantly lower when compared with those from agematched healthy controls. Although crisis $\mathrm{TxB}_{2}$ levels were significantly elevated compared with those in steady state levels, they were still reduced when compared with the levels assayed in controls. Such changes in basal $\mathrm{TxB}_{2}$ levels in patients with SCD in steady state and crisis have previously been documented in one study (11), whereas others have shown elevated levels of this eicosanoid in steady state patients with the levels either remaining unchanged or increasing further during crisis $(9,12)$.

The discrepancies in published results suggest differences in patient groups and methodologic differences in blood sampling and assays for $6 \mathrm{kPGF}_{1 \alpha}$ and $\mathrm{TxB}_{2}$. All of the blood levels hitherto reported were obtained from direct assay of either plasma or serum samples employing different pharmacologic agents to suppress eicosanoid production by the cellular elements of blood. In addition, as shown in this study as well as by other investigators $(18,19)$, direct RIA of prostanoids in biologic fluids is subjected to either positive or negative interferences. Finally, the eicosanoid levels in several plasma samples reported here and in many of the published reports were either below the detection level or very close to the lower limit of the assay's sensitivity when plasma was assayed directly. To obviate these previously identified methodologic problems, in this investigation the eicosanoids were extracted from larger sample volumes of plasma $(3-5 \mathrm{~mL})$, separated by reverse phase-HPLC, and only then assayed by immunoassay procedures.

Vascular endothelium is the major source of plasma prostacyclin. Previous studies have shown that plasma stimulates prostacyclin production by endothelial cells (20-22). Using Remuzzi et al.'s (23) exhausted human umbilical arterial seg-

Table 1. Plasma $6 \mathrm{kPGF}_{1 \alpha}$ levels in children with $S C D$

\begin{tabular}{|c|c|c|}
\hline Reference & Methodology & Observation \\
\hline Mehta and Albiol (7) & $\begin{array}{l}\text { Plasma prepared in the presence of } 1 \mathrm{mM} \\
\text { aspirin was assayed directly. Most of the } \\
\text { control levels were below detectable } \\
\text { levels }\end{array}$ & $\begin{array}{l}6 \mathrm{kPGF}_{1 \alpha} \text { levels in children with steady state SCD } \\
\text { were significantly higher compared to age- and } \\
\text { sex-matched controls }\end{array}$ \\
\hline Longenecker and Mankad (8) & $\begin{array}{l}\text { Serum prepared in the presence of } \\
\text { indomethacin was assayed directly }\end{array}$ & $\begin{array}{l}6 \mathrm{kPGF}_{1 \alpha} \text { levels in children with steady state SCD } \\
\text { were significantly lower compared to age-matched } \\
\text { controls. Crisis levels were higher compared with } \\
\text { steady state levels }\end{array}$ \\
\hline Buchanan and Holtkamp (9) & $\begin{array}{l}\text { Plasma prepared in the presence of } 25 \\
\mu \mathrm{g} / \mathrm{mL} \text { indomethacin was assayed } \\
\text { directly. Pediatric patients were compared } \\
\text { with controls comprising at least } 75 \% \\
\text { adult population }\end{array}$ & $\begin{array}{l}\text { Steady state } 6 \mathrm{kPGF}_{1 \alpha} \text { levels were higher than the } \\
\text { control levels. Crisis levels were similar to those } \\
\text { obtained with steady state }\end{array}$ \\
\hline Koren (Kurlat) and Halevi (10) & Plasma was assayed directly & $\begin{array}{l}6 \mathrm{kPGF}_{1 \alpha} \text { levels in children with steady state SCD } \\
\text { were slightly higher than in age-matched control. } \\
\text { Crisis levels were significantly lower compared } \\
\text { with steady state levels }\end{array}$ \\
\hline Longenecker et al. (11) & $\begin{array}{l}\text { Serum prepared in the presence of } 13.9 \\
\mu \mathrm{M} \text { indomethacin was assayed directly }\end{array}$ & $\begin{array}{l}6 \mathrm{kPGF}_{1 \alpha} \text { levels in children with steady state SCD } \\
\text { were significantly lower compared to age- and } \\
\text { race-matched controls. Early crisis levels were } \\
\text { lower than the steady state levels }\end{array}$ \\
\hline
\end{tabular}


ments, we have previously demonstrated that the in vitro prostacyclin-regenerating ability of steady state SCD plasma is markedly decreased when compared with control plasma (24). These studies, therefore, suggest that the abnormal circulatory $6 \mathrm{kPGF}_{1 \alpha}$ levels in SCD may be due to modulation of endothelial prostacyclin production by sickle plasma components. Biochemical changes that occur in cells after activation include mobilization of AA from membrane phospholipids and conversion of the mobilized AA via the cyclooxygenase and prostacyclin synthase pathway to prostacyclin. Modulation of one or more of these biochemical events by sickle plasma may result in a decrease in circulatory $6 \mathrm{KPGF}_{1 \alpha}$ levels. The decreased ability of steady state SCD plasma to stimulate prostacyclin production in vitro appears to be due to a modulatory effect of SCD plasma components on processes distal to AA mobilization, because both control and steady state SCD plasma stimulated the release of AA almost to the same extent (Fig. 5). Our results also indicate that the activity of cyclooxygenase is affected by SCD plasma, because both total prostanoid production (a measure of cyclooxygenase activity) and prostacyclin formation decreased in parallel. Plasma components could interfere with the cyclooxygenase reaction either by reducing the availability of free AA for enzymatic reaction or by inhibiting the enzyme directly. These plasma effects have not been further characterized. Another possible mechanism by which steady state SCD plasma may induce changes in prostacyclin production includes depletion of the substrate as a result of continuous or repeated endothelial activation. This possibility is seemingly excluded from our in vitro studies, because the cells subjected to treatment with different plasmas had similar amounts of substrate arachidonic acid in their membrane phospholipids. However, this could be an additional factor in modulating prostacyclin production in vivo in patients with SCD.

During VOC there appear to be higher circulating levels of $6 \mathrm{kPGF}_{1 \alpha}$ than in steady state. This finding goes hand in hand with our further observation that prostacyclin-regenerating activity is also relatively increased. The increased prostacyclinregenerating activity that we have observed in the presence of crisis plasma was not due to an activation of the enzymes cyclooxygenase or prostacyclin synthetase by crisis plasma components, but rather due to an increased release of the substrate, arachidonic acid, from the storage pools for enzymatic conversion. This conclusion was supported by the observations that the crisis plasma mobilized 2-4 times more $\mathrm{AA}$, compared with steady state plasma, and that the ratio of prostanoids produced to the amount of AA mobilized remained the same with both steady state and crisis plasma preparations.

Vaso-occlusion in SCD is a complex and a multifactorial process $(1,2)$. Increased adherence of sickle red cells to endothelium is suggested to be one of the important events in the initiation and propagation of vaso-occlusion. Although altered erythrocyte membrane surface properties of sickle red cells and plasmatic factors have been reported to play important roles in the adhesiveness of red cells, the adherence process is further potentiated by microvascular hemodynamics and cellular factors including platelet-platelet, platelet-endothelial, and leucocyte-endothelial interactions $(1,2)$. Prostacyclin (a potent va- sodilator and anti-thrombotic eicosanoid) and $\operatorname{Tx} \mathrm{A}_{2}$ (a potent vasoconstrictor and prothrombotic eicosanoid) may modulate the pathogenesis of vaso-occlusion by affecting one or more of these processes. The role of cyclooxygenase metabolites including prostacyclin on red cell-endothelial cell adherence has previously been evaluated with conflicting results. Wautier and co-workers found that although exogenously provided prostacyclin stimulated adherence, inhibition of endogenous prostacyclin production by flurbiprofen (a cyclooxygenase inhibitor), had no effect on the adherence process $(25,26)$. In contrast, other investigators have demonstrated that iloprost (a stable analog of prostacyclin) inhibited the adherence process (27). In a recent study using human retinal microvascular endothelial cells, we have demonstrated that carbacyclin (a stable synthetic prostacyclin analog with biologic properties similar to prostacyclin) had no effect on the adherence process when evaluated at concentrations between $10 \mathrm{pM}$ and $1 \mu \mathrm{M}$ (28). The conflicting results reported in the literature on the role of prostacyclin on red cell-endothelial cell adherence could be due to differences in the cell systems employed and also due to methodologic differences associated with these studies. Although the levels of prostacyclin are, therefore, seemingly not relevant to the adherence process per se, prostacyclin can alter microcirculatory perfusion either through a direct vasodilatory effect or by counteracting the vasoconstrictor effect of $\mathrm{TxA}_{2}$, and thus by these latter mechanisms potentially affect the vasoocclusive phenomenon. Prostacyclin may also play an important role in the pathogenesis of vaso-occlusion in SCD by modulating the interaction of platelets and leukocytes with the endothelium, because this eicosanoid inhibits a variety of platelet and leukocyte functions either directly or through its counter effect on the potentiating effects induced by $\mathrm{TxA}_{2}(29)$. Thus, an abnormal balance between the synthesis of these two vasoactive eicosanoids favoring vasoconstriction may play an important role in the initiation and propagation of VOC in patients with SCD. Although a decreased release of prostacyclin by endothelium has been previously suggested to be one of the factors precipitating VOC, our study demonstrates a relative increase during VOC of $6 \mathrm{kPGF}_{1 \alpha}$ levels over those observed in steady state. However, when the ratio of $\mathrm{TxB}_{2}$ to $6 \mathrm{kPGF}_{1 \alpha}$ was calculated, a significant increase in this ratio, i.e. a preponderance of the vasoconstrictor eicosanoid was noted during VOC compared with steady state. Because activated platelets release $\mathrm{TxA}_{2}$, the relative increase in plasma $\mathrm{TxB}_{2}$ observed in this study in patients with SCD during VOC could be a consequence of platelet activation, a pathophysiologic process that has been shown to occur in vivo in sickle cell patients during crisis when compared with steady state $(30-32)$.

In summary, we have demonstrated that the $6 \mathrm{kPGF}_{1 \alpha}$ and $\mathrm{TxB}_{2}$ levels in children with SCD in steady state are significantly lower when compared with those from age-matched controls. Decreased circulatory $6 \mathrm{kPGF}_{1 \alpha}$ levels in patients with SCD in steady state may be due to sickle plasma-induced impairment in endothelial cell prostacyclin production. Although the plasma level of $6 \mathrm{kPGF}_{1 \alpha}$ increases during VOC, the rise is accompanied by an increase in levels of $\mathrm{TxB}_{2}$ such that the ratio of $\mathrm{TxB}_{2}$ to $6 \mathrm{kPGF}_{1 \alpha}$ is significantly increased in crisis when compared with the steady state. This imbalance in the 
ratio of constrictor to dilator eicosanoids could potentially play a role in the potentiation of VOC in patients with SCD.

Acknowledgments. The authors thank the staff members of the division of Hematology-Oncology, St. Christopher's Hospital for Children, for their co-operation in obtaining blood samples from donors, all volunteers for their generous donation of blood samples for these studies, and Sujatha Setty for typing this manuscript.

\section{REFERENCES}

1. Hebbel RP 1991 Beyond hemoglobin polymerization: The red blood cell membrane and sickle disease pathophysiology. Blood 77:214-237

2. Francis Jr RB, Johnson CS 1991 Vascular occlusion in sickle cell disease: Current concepts and unanswered questions. Blood 77:1405-1414

3. Majerus PW 1983 Arachidonate metabolism in vascular disorders. J Clin Invest 72:1521-1525

4. Bunting S, Moncada S, Vane JR 1973 The prostacyclin-thromboxane $\mathrm{A}_{2}$ balance: Pathophysiological and therapeutic implications. Br Med Bull 39:271-276

5. Colwell JA, Halushka PV, Sarji KE, Lopes-Virella MF, Sagel J 1979 Vascular complications in diabetes. Arch Intern Med 139:225-230

6. Willis AL, Smith DL, Vigo C 1986 Suppression of principal atherosclerotic mechanisms by prostacyclin and other eicosanoids. Progr Lipid Res 25:645-666

7. Mehta P, Albiol L 1982 Prostacyclin and platelet aggregation in sickle cell disease. Pediatrics 70:354-356

8. Longenecker GL, Mankad V 1983 Decreased prostacyclin levels in sickle cell disease. Pediatrics 71:860-861

9. Buchanan GR, Holtkamp CA 1985 Plasma levels of platelet and vascular prostaglandin derivatives in children with sickle cell anaemia. Thromb Haemostasis 54:394396

10. Koren (Kurlat) A, Halevi R 1989 Decreased prostacyclin levels in sickle-cell disease. Pediatr Hematol Oncol 6:67-69

11. Longenecker GL, Beyers BJ, Mankad VN 1992 Platelet regulatory prostanoids and platelet release products in sickle cell disease. Am J Hematol 40:12-19

12. Mehta P 1981 Increased plasma thromboxane levels in sickle cell disease. Pediatr Res 15:582

13. Glaser BM, D'Amore PA, Michels RG, Patz A, Fenselau A 1980 Demonstrations of vasoproliferative activity from mammalian retina. J Cell Biol 84:298-304

14. Setty BNY, Phelps DL, Walenga RW, Stuart MJ 1991 Identification of prostaglandins and hydroxyeicosatetraenoic acids in kitten retina: Comparison with other species. Exp Eye Res 53:81-88
15. Setty BNY, Stuart MJ 1986 15-Hydroxy-5,8,11,13-eicosatetraenoic acid inhibits human vascular cyclooxygenase: Potential role in diabetic vascular disease. J Clinic Invest 77:202-211

16. Bligh EG, Dyer WJ 1959 A rapid method of total lipid extraction. Can J Biochem Physiol 37:911-917

17. Lapetina EG, Cuatreacasas P 1979 Stimulation of phosphatidic acid production in platelets precedes the formation of arachidonate and parallels the release of serotonin. Biochim Biophys Acta 573:394-402

18. Salmon JA 1983 Measurement of eicosanoids by bioassay and radioimmunoassay. $\mathrm{Br}$ Med Bull 39:227-231

19. Morris HG, Sherman NA, Shepperdson FT 1981 Variables associated with radioimmunoassay of prostaglandins in plasma. Prostaglandins 21:771-778

20. Seid JM, Jones PBB, Russell RGG 1983 The presence in normal plasma, serum and platelets of factors that stimulate the production of prostacyclin $\left(\mathrm{PGI}_{2}\right)$ by cultured endothelial cells. Clin Sci 64:387-394

21. Deckmyn H, Zoja C, Arnout J, Todisco A, Vanden Bulcke F, D'Hondt L, Hendrickx N, Gresele P, Vermylen J 1985 Partial isolation and function of the prostacyclin regulating plasma factor. Clin Sci 69:383-393

22. Mikkola T, Ristimaki A, Viinikka L, Ylikorkala O 1993 Human serum, plasma, and platelets stimulate prostacyclin and endothelin-1 synthesis in human vascular endothelial cells. Life Sci 53:283-289

23. Remuzzi G, Mecca G, Misiani R, Livio M, de Gaetano G 1978 Haemolytic-uraemic syndrome: deficiency of plasma factor(s) regulating prostacyclin activity (?). Lancet 2:871 872

24. Stuart MJ, Sills RH 1981 Deficiency of plasma prostacyclin or $\mathrm{PGI}_{2}$ regenerating ability in sickle cell anaemia. Br J Haematol 48:545-550

25. Pinigny D, Wautier JL, Wautier MP, Caen JP 1989 Modification of membrane properties of erythrocytes by $\mathrm{PGI}_{2}$. Thromb Res 54:643-653

26. Wautier JL, Pintigny D, Maclouf J, Wautier MP, Corvazier E, Caen J 1986 Release of prostacyclin after erythrocyte adhesion to cultured vascular endothelium. $\mathbf{J} \mathrm{Lab}$ Clin Med 107:210 -215

27. Longenecker G, Beyers B, McNullan E 1989 Iloprost and red cell-endothelium interactions. J Vasc Med Biol 1:100A

28. Setty BNY, Dampier CD, Stuart MJ 1993 Human microvascular endothelial cell sickle red cell adherence-role of lipoxygenase-derived eicosanoids. Blood 82:351A

29. Vane JR 1982 Prostacyclin: A hormone with a therapeutic potential. J Endocrinol 95:3P-43P

30. Haut MJ, Cowan DH, Harris JW 1973 Platelet function and survival in sickle cell disease. J Lab Clin Med 82:44-53

31. Semple MJ, Al-Hasani SF, Kioy P, Savidge GF 1984 A double-blind trial of ticlopidine in sickle cell disease. Thromb Haemostasis 51:303-306

32. Beurling-Harbury C, Schade SG 1989 Platelet activation during pain crisis in sickle cell anemia patients. Am J Hematol 31:237-241 